\title{
Case Report Infestasi Psitocobrossus sp pada Macaw (Ara macao)
}

\author{
Case Report of Psitocobrossus sp Infestation in Macaw (Ara macao)
}

Yesica R1, Kusumarini S1, Giarli D.U2, Wulandari E2, Dewi F.W.K², Nabila I2, Firsty N2, Purba O2, Sari S.T.P2, Pramesti T.L2, Armanto T.Y², Puspita Y.Y²

${ }^{1}$ Laboratory of Veterinary Medicine, Faculty of Veterinary Medicine, Universitas Brawijaya

${ }^{2}$ Doctor of Veterinary Medicine Program, Faculty of Veterinary Medicine, Universitas Brawijaya

*email: rezayesica@ub.ac.id

\begin{abstract}
ABSTRAK
Macaw termasuk jenis burung yang berukuran besar dan bersuara keras. Dengan nama latin Ara macao, burung ini mempunyai sifat yang lincah, cerdas, dan sangat ramah. Di dunia terdapat 18 spesies macaw, beberapa di antaranya termasuk spesies yang dilindungi. Ektoparasit merupakan salah satu parasit yang banyak ditemukan pada hewan peliharaan dan satwa liar. Salah satu ektoparasit yang sering menyerang burung adalah infestasi kutu. Kutu (lice) memakan bulu dan kulit. Spesies kutu eksklusif dalam kelompok burung beo adalah Psittacobrosus. Kutu ini termasuk dalam keluarga menoponidae. Dalam penelitian ini diambil sampel dari macaw betina berumur 3 tahun yang dibawa ke Rumah Sakit Hewan Pendidikan Universitas Brawijaya. Hasil pemeriksaan menunjukkan bahwa ektoparit yang diduga tergolong Psittacobrosus sp. Pengobatan yang digunakan pada kasus ini adalah dengan Carbaryl 5\%, Tetraclorvinphos spray 0,5\% serta menjaga kebersihan kandang.
\end{abstract}

Kata Kunci: Macaw, Psittacobrosus, Ektoparasit

\begin{abstract}
Macaws are large birds, including having a louder sound. Macaws are lively, intelligent and very friendly birds. In the world, there are 18 species of macaws, some of which belong to protected species. Ectoparasites are one of the parasites commonly found in domestic and wild animals. One of the ectoparasites that often attacks birds is feather lice infestation. They eat fur and skin. The exclusive lice species in the parrot group is Psittacobrosus. Psittacobrosus is included in the chewing lice. These lice belong

(C)2020. Yesica et al. Open access under CC BY - SA license, doi: 10.20473/mkh.v31i1.2020.11-22

Received: 23-08-2019, Accepted: 08-10-2019, Published online: 29-01-2020

Available at https:/ / e-journal.unair.ac.id/MKH/index
\end{abstract}


to the family of menoponidae. In this study we collected the sample from the 3 year old female macaw that was taken to Animal Education Hospital Universitas Brawijaya. The examination result showed that the ectoparites identified as Psittacobrosus sp. The treatment that being used from this case are with Carbaryl 5\%, Tetraclorvinphos spray $0,5 \%$ and also maintaining the sanitary of the cage.

Keywords: Macaw, Psittacobrosus, Ectoparasite

\section{INTRODUCTION}

Macaws are large size with loud

sound, intelligent and very friendly

birds. Macaws tend to like to bite, especially toys made by wood. This is

for hone the strength of the beak and the form of interaction. The natural habitat of macaw is in the forests in the North American region (Mexico), Central and South. The Caribbean region is also the natural habitat of the Cuban macaw (Ara tricolor) and Saint Croix macaw (Ara autochthones) (Jonker et al., 2012).

In the world, there are 18 species of macaws, some of its belong to protected species. Species that can be preserved are blue and gold macaw (Ara ararauna), green winged macaw (Ara chloropterus), Hahn macaw (Diopsittaca nobilis), Hyacinth (Anodorhynchus hyacinthinus), Scarlet macaw (Ara macao), macaw military (Ara militarist), and macaw severe (Ara severus) (Pranty et al., 2010). Ectoparasite is the parasite commonly found in domestic and wild animals. One of the ectoparasite that often attacks birds is feather lice infestation. They eat fur and skin. These louse can be dangerous for domestic and wild animals, because they reduce the quality of fur, provoke small holes in the fur (which reduces 
the thermoregulatory capacity), and increase fur damage. To date, more than 4000 species of bird lice have been identified worldwide (Girisgin et al., 2013). The exclusive lice species in the parrot group is Psittacobrosus. Psittacobrosus is included in the chewing lice. These lice belong to the family of menoponidae (Valim M.P et al., 2009).

In this study, we provide data from one of the lice that found in macaws starting from sampling and laboratory examination. Further data from this collection will be important for identifying the lice from macaws.

\section{MATERIALS AND METHOD}

\section{Clinical Symptoms and Examination}

A 3 years old female macaw with

$2 \mathrm{~kg}$ body weight mixed in red, yellow, and blue is taken to the Animal
Education Hospital University of Brawijaya. It was found that there was a lump on the root of the feather on the right wing from the results of physical examination.

\section{Laboratory Examination}

Laboratory examination of Macaw, the ectoparasite samples taken directly from Macaw wings feathers. Ectoparasite examination was performed by mounting method without coloring.

\section{RESULTS}

Examination results in Macaw found that lice are suspected to be Psitacobrosus sp. with 12 segments of the abdomen, 1 pair of antennas and 3 pairs of legs. Based on the history, clinical symptoms, physical examination, and examination of 
Macau bird was diagnosed with prognosis.

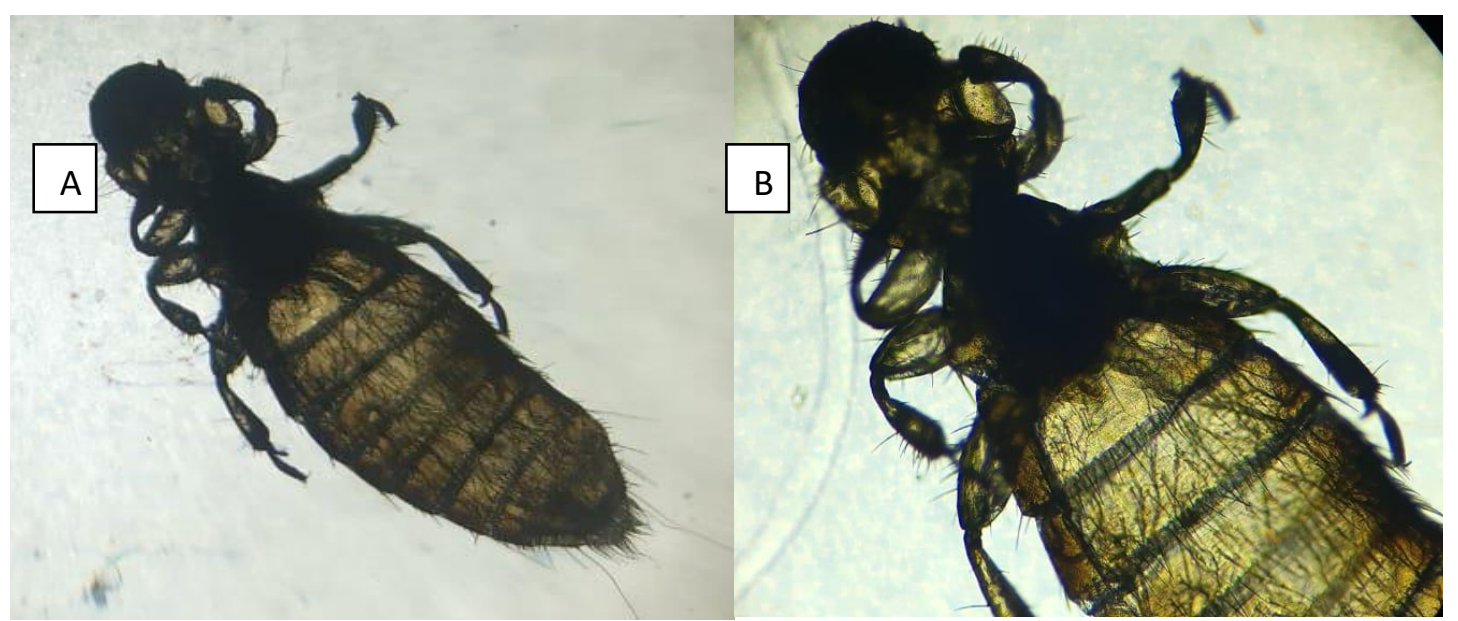

Fig.1 (A) Psittacobrocus at 40x magnification. (B). Psittacobrocus at 100x magnification

\section{DISCUSSION}

Birds affected by ectoparasites can experienced weight loss, feather loss, irritation, anemia and death. Rose (2005) reports that birds infected with Cnemidocoptes sp. can cause hyperkeratosis and also death. Research by Schmaschke et al. (2002) showed birds infected with ectoparasites could have immunosurppression. Cotgreave and Clayton (1994) report that losses caused by the presence of ectoparasites not only affect health but also give effect for the birds activities, namely preening, dusting, sunning, earrings, bill wipping, water bathing, smoke bathing and scratching.

Preening activity is behavior in birds that aims to treat feathers. The preening activity is not only to clean 
and treat the feather, but also to remove ectoparasites. In general, an increasing frequency of preening activities is followed by an increase in the number of ectoparasites. The difference in the prevalence of ectoparasites is due to the adaptability of ectoparasites in the host body and the compatibility of the host for the survival of the parasite (Findyandini et al., 2012). This is same as with Schmaschke et al. (2002) who reported that D. melopsittacus and Psittacobrosus $s p$ is a type of ectoparasites that commonly attack birds of the family Psittacidae such as macaw. Wall and Shearer (2001) state that the high percentage of the prevalence of this type is due to the lifestyle of the macaws in groups, resulting in the rapid spread of ectoparasites.
The prevalence rate of ectoparasites is influenced by several factors including age, sex, breeding, climate, and maintenance management. Ectoparasites generally attack young birds (under one year old). That is because young birds have low endurance. The lack of cleanliness of the cage at the time of the study also affect the spread of ectoparasites (Fauzi, 2013). This is in accordance with the research of Bahtiar et al (2014) who reported that the cleanliness and maintenance of the cage that was not given enough attention were the main source of ectoparasite so that good maintenance of the cage affected the presence of ectoparasites.

The behavior that is often shown by the Psittacidae family such as macaw for self-defense from 
ectoparasites, namely by allopreening

and scratching (Harrison et al., 1994). Allopreening is the behavior of birds do preening activities to other birds (Brooke, 1985). Allopreening is one of the activities that birds live in pairs. Harrison et al. (1994) reported that groups of birds in pairs often spending time to play and it is including allopreening activities. Based on the Spearman correlation analysis, the frequency between preening activities and total ectoparasites shows a different significant value, which is $0.00<0.01$. This shows that there is a relationship between the frequency of preening activity with the amount of ectoparasites in macaw. Clayton et al. (2010) reported that the increase in preening activity in macaw was caused by birds infected by ectoparasitic. It is responding to the preening activity to reduce ectoparasites in their bodies. Preening is done by biting the feathers with both beaks then pulled so that the strands of hair or barb will be pulled out. Some birds preen for so long that they damage the feather. Feathers are ectoparasites favourite because they are suitable as a place for breeding and survival. The small beak size facilitates preening so its very efficient for cleaning ectoparasitic arthropods. However, macaws have sharp beaks and when they in preening activities many feathers are damaged or revoked (Bush et al, 2012). Feather damage in macaws can be seen on the chest because the chest feathers are thin feathers so they will fall out or break when birds scratch or trace. Bahtiar et al (2014) reported that loss of macaw 
feathers due to ectoparasite can cause

birds to be agitated, stressed and easily

ill due to decreased immunity due to lack of appetite.

Diseases such as skin irritation

because ectoparasite can attack and reduce appetite. Crooked beak birds are more sensitive to ectoparasites because of changes in behavior that tends to be silent and difficult to eat when attacked by ectoparasite. According to Loye and Carroll (1998), ectoparasite infestations greatly affect reproductive performance because they can cause bird death. Ectoparasite more often attack birds that live in nests and cause birds to prefer leaving the nest. Ectoparasite is a classic problem that is detrimental, but doesn't receive much attention. The losses incurred are very large ranging from weight loss of birds, decrease production, freathers loss, trauma, irritation, anemia and even death (Kusuma, 2008).

Psittacobrosus burmeisteri is a new flea subspecies for the red and green Ara macao (Guacamayo escerlata) which lives in Argentina, Brazil, Bolivia, Colombia and Venezuela (Gomez-Puerta and Vega, 2018). Group of Psittacobrosus morphological based on the head, thorax and abdomen. Pre-ocular margin of head more or less circular; temples rounded but not strongly expanded with occipital margin concave and one pair large antennas. Thorax part is divided into prothorax, pterothorax and mesothorax. Prothorax is large, winged and with circular posterior margin. Pterothorax comparatively 
small with posterior margin transverse

in both sexes. Mesothoracic part is very

short with a meso-metathoracic sternal

suture. Abdomen elongated oval with

twelve segmens abdoments, much

longer and somewhat pointed apically in the female and circular in male.

Generally length of the Psittacobrosus sp is about $2.4 \mathrm{~mm}$. Overall, males smaller than females but otherwise the same in all structure excepting the shape and abdominal segments.
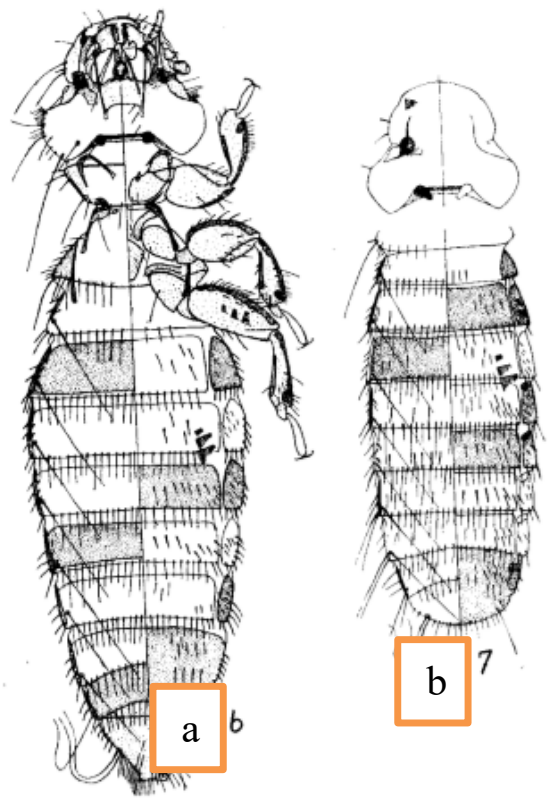

Figure a. Female Psittacobrosus sp b. Male Psittacobrosus sp 
Birds affected by fleas can be treated by spraying on individual or bird colonies in one cage. Individual treatment with flea infestation can be given Permethrin spray $1 \%$, while in colony it can be controlled using Carbaryl powder $5 \%$ and Tetrachlorvinphos spray $0.5 \%$. Whatever method is used, make sure that the bird is fully covered with insecticide. If spraying is done, it must be ensured that the part of the feather under the wing is sprayed, because it is usually a flea predilection (Hastutiek dkk., 2014).

Prophylactic action by maintaining the sanitary cage must be done. Sanitary cage is an activity carried out to maintain the cleanliness of the cage and the environment around the cage. Cage sanitation program is important to keep the cage and the environment around the cage clean to cut the life cycle of fleas. The cage sanitation program is cleaning the cage regularly with disinfection.
Disinfection of the cage can use benzalkonium chloride $10 \%$ by spraying on the cage area (Reiss and Woods, 2011). Disinfection of ground-based cages can use limestone, where it has high alkaline properties so it is widely used to reduce soil acidity. In addition, limestone also serves to stabilize moist soil conditions because it has high water absorption.

\section{CONCLUSION}

Ectoparasite is one of the parasites commonly found in domestic and wild animals. One of the ectoparasite that often attacks birds is feather lice. The exclusive lice species in the parrot group is Psittacobrosus. Treatment of birds affected by fleas is spraying on individual or bird colonies in one cage and the bird is fully covered with insecticide. If spraying was done, it must be ensured that the 
part of the feather under the wing is sprayed, because it is flea predilection.

\section{REFERENCES}

Bahtiar, D.H, R. Susanti dan M. Rahayuningsih .2014

Keanekaragaman

Jenis

Ektoparasit Burung Paruh

Bengkok Famili Psittacidae di

Taman Margasatwa Semarang.

Unnes. Journal of Life Science, 3(2):139- 147.

Brooke, M.D.L .1985. The Effect Allopreening on Tick Burdens of Molting Eudyptid Penguins. Auk. 102:893-895

Bush, S.E, S.M Villa, D. Brewe, J.R Belthoff .2012. Influence of Bill and Foot Morphology on the Ectoparasites of Barn Owls.
Journal of Parasitology, 98(2): 256-261.

Clayton, D.H, J.A.H Koop, C.W Harbison, B.R Moyer, S.E Bush .2010. How Birds Combat Ectoparasites. The Opening Ornithology Journal, 3: 41-71.

Cotgreave, P dan D.H Clayton .1994. Comparative Analysis of Time Spent Grooming by Bird in Fauzi, F.N. 2013. Lovebird. Klaten: PT Hafamira.

Findyandini, H.P, S. Subekti, Kismiyati. 2012. Identifikasi dan prevalensi ektoparasit pada Ikan Bandeng (Chanos chanos) yang dipelihara di karamba jarring apung UPBL Situbondo dan di Tambak Desa Bangunrejo Kecamatan Jabon Sidoarjo. 
Journal of Marine and Coastal

Science, 1(2): 91-112.

Girisgin, A. O., B. Dik and O. Girisgin. 2013. Chewing Lice (Phthiraptera) Species of Wild Birds in Northwestern Turkey with a New Host Record. International Journal of Parasitology. 2:217-221.

Ritchie B.W, G.J Harrison and L.R Harrison .1994. Avian Medicine: Principles and Application. Florida:Winger Publishing, Inc.

Hastutiek, P., R. Sasmita, A. Sunarso, M. Yunus. 2014. Ilmu Penyakit Artropoda Veteriner. Airlangga University Press.

Jonker, R.M.V. and W.L.M. Tamis. 2012. Introduction, Breeding and Poaching of Scarlet Macaws (Ara macao L.) in a Temperate
Country. Journal of Ornithology.5:1-4.

Kusuma, S. 2008. Masalah Infestasi Ektoparasit Pada beberapa Jenis Burung Elang di Habitat Eks-situ. (Skripsi). Bogor: Institut Pertanian Bogor.

Loye, J.E and S.P Carroll .1998. Ectoparasite Behavior and Its Effects on Avian Nest Site Selection. Jurnal Entomologi 91(2): 159-163

Pranty, B., D. Fienstein and K. Lee. 2010. Natural History of Blueand-Yellow Macaws (ara ararauna) in Miami-Dade County Florida. Florida Field Naturalist 38(2):55-62.

Gomez-Puerta, L.A. and C.L. Vega. 2018. Contribution to the Knowledge of the Mallophaga 


\begin{tabular}{|c|c|}
\hline (Phthiraptera, & of Chewing Lice (Insecta, \\
\hline Ischnocera) of the Birds from & Ptiraptera) from \\
\hline Peru part 2. National University & Southern \\
\hline Mayor de San Marcos. Faculty & Description of New Species. \\
\hline Veterinary & Iheringia Serie Zoologia 99 (3):249- \\
\hline Laboratorium Epidemiology & 258 \\
\hline and Economic Veterinary. San & D. Shearer .2001. \\
\hline Borja, Lima, Peru & Ectoparasites: \\
\hline A. E. and R.W. Woods .2011. & Biology, Pathology and Control. \\
\hline Vational Zoo Biosecurity Manual & Edition. \\
\hline
\end{tabular}

Behaviour, 131(3-4):171-187.

Rose, K .2005. Common Diseases of Urban Wildlife: Birds. Part one. The Australian Registry of Wildlife Health

Schmaschke, R, R. Schone , M. Sachse and K. Eulenberger .2002. Feather Mites of Psittacidae. Makalah.

Valim, P.M., M. Francine., Lambrecht and E.S Elvia .2009. New Record 